\title{
Friction Free Force-Reflecting Type Bilateral Control Based on Twin Drive System Considering 2nd Resonant Frequency and Unbalance Friction
}

\author{
Yuzuru Ohba Student Member (Nagaoka University of Technology) \\ Kiyoshi Ohishi Senior Member (Nagaoka University of Technology) \\ Seiichiro Katsura Member (Nagaoka University of Technology)
}

Keywords: bilateral control, multi-inertia system, state-feedback, twin drive system, reaction force estimation observer, tortional vibration, force-feedback type, friction free free

This paper proposes a new friction free bilateral system based on twin drive control system considering it's resonant frequency. The twin drive system consists of two motors that are coupled by the differential gear. The output torque becomes a differential torque of both motors. The nonlinear friction torque of the twin drive system is easily compensated. However, this system has the resonant frequencies and the anti-resonant frequencies which are caused by the torsional vibration. This paper proposes a new three-inertial-model of twin drive system, and identifies the resonant frequencies and it's friction torque. The proposed controller can suppress the torsional vibration without high order control design. Therefore, the operationality of bilateral teleoperation is improved by the proposed system.

Fig. 1 shows the proposed vibration suppression control system. Fig. 2 show the experimental results of the proposed force-reflecting type bilateral system. Fig. 2(a) is result without vibration suppression control. Fig. 2(b) is result of two mass designed vibration suppression controller. And Fig. 2(c) is result of three mass designed vibration suppression controller with two mass observer.

The conventional control method has vibration phenomenon. However, the proposed control method has no vibration phenomenon in comparison with the control method without vibration suppression control loop.

From Fig. 2, the experimental results confirm that the can proposed vibration suppression control system suppresses the torsional vibration, without reducing the bandwidth of the system.

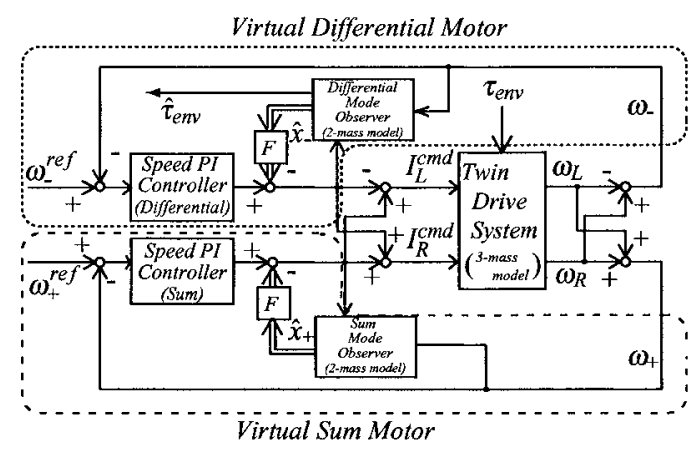

Fig. 1. Proposed vibration suppression controller for twin drive system

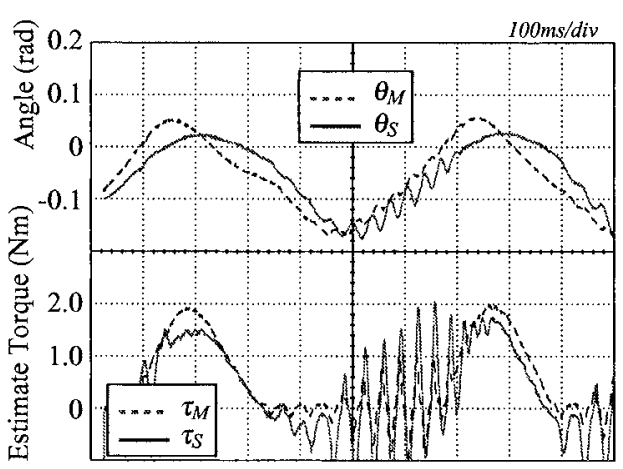

(a) Result of two-mass model designed controller (broad bandwidth)

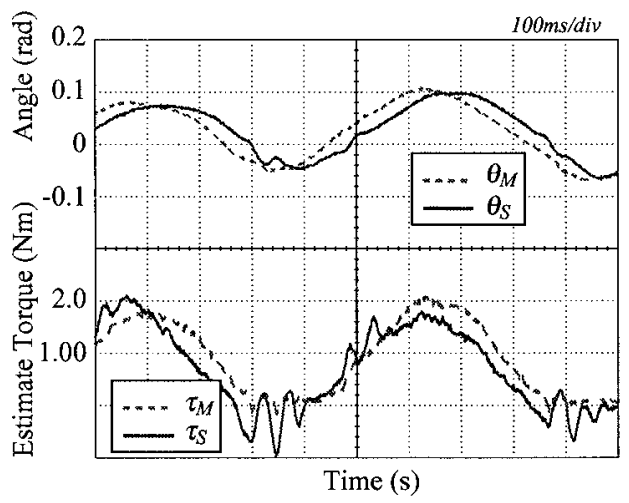

(b) Result of two-mass model designed controller (broad bandwidth)

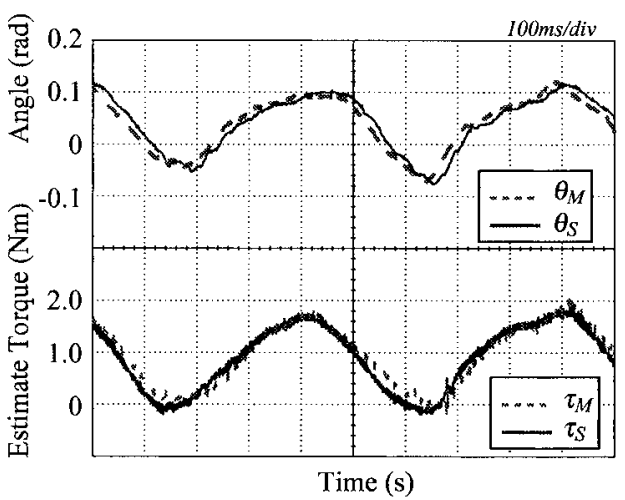

(c) Result of three-mass model designed controller

Fig. 2. Experimental results of the bilateral response using twin drive system 


\title{
ツインドライブシステムの2次共振と不平衡摩擦を考慮した 摩擦フリー力帰還型バイラテラル制御
}

\author{
学生員 大場 譲* 上級会員 大石 潔* \\ 正 員 桂 誠一郎*
}

\author{
Friction Free Force-Reflecting Type Bilateral Control Based on Twin Drive System \\ Considering 2nd Resonant Frequency and Unbalance Friction \\ Yuzuru Ohba*, Student Member, Kiyoshi Ohishi*, Senior Member, Seiichiro Katsura*, Member
}

\begin{abstract}
This paper proposes a new friction free bilateral system based on twin drive control system considering it's resonant frequency. The twin drive system consists of two motors that are coupled by the differential gear. The output torque becomes a differential torque of both motors. The nonlinear friction torque of the twin drive system is easily compensated. However, this system has the resonant frequencies and the anti-resonant frequencies which are caused by the torsional vibration. This paper proposes a new three-inertial-model of twin drive system, and identifies the resonant frequencies and it's friction torque. The proposed controller can suppress the torsional vibration without high order control design. Therefore, the operationality of bilateral teleoperation is improved by the proposed system.
\end{abstract}

キーワード：バイラテラル制御，多慣性系，ツインドライブシステム，反カオブザーバ，力帰還，摩擦フリーシステム，係数 図法

Keywords: bilateral control, multi-inertia system, twin drive system, reaction force estimation observer, force-feedback type, friction free system, coefficient diagram method

\section{1.はじめに}

ロボティクス技術の発展と共に，ロボットに作業を代行 させることで，人間の負担を減らす試みが多々なされてい る。その試みの中にバイラテラルシステムが存在し, 位置 情報と力情報を相互にやり取りして，その場での作業感覚 を操作者へ与えることができる。

力覚を伝達するための力情報の取得には従来力センサを 用いてきた。しかしながら，力センサには取り付け位置の 問題，ノイズ除去のためのフィルタによる带域の制約など が存在する。その結果良好な力覚の伝達を阻害することに なる。反力オブザーバ(1) (3) を用いた力センサレス制御を行 うことで広帯域な力情報の取得が可能であるが, 帯域の向上 とともに非線形摩擦の影響と機械共振の影響が問題となる。

そこで，摩擦を補償するためにツインドライブシステム が既に提案されている(4) -(6)。ツインドライブシステムは 2 つのモータを用いて 1 軸を駆動するシステムであり，機構的 に摩擦を打ち消すことで容易な摩擦補償を実現できる。し

\footnotetext{
*長岡技術科学大学

于 940-2188 長岡市上富岡町 1603-1

Nagaoka University of Technology

1603-1, Kamitomiokamachi, Nagaoka 940-2188
}

かしながら，ツインドライブシステムにはギア付きモータ を用いている。ギアを用いているシステムは，軸ねじり振 動による共振周波数を持つことが一般的に知られており (7), ツインドライブシステムも共振の影響を受ける。

これに対し筆者らは 3 慣性系のモデル化を行い, そのモ デル上で 1 次共振モードのみを考慮した制振制御系を設計 し, 結果ツインドライブシステムの位置制御系の応答は制 振制御を行わない図 1(a) と比較して，図 1(b) と格段の性 能向上を図ることができている ${ }^{(8)}$ 。

しかし実際のツインドライブシステムは 2 次共振モード を持つ 3 慣性系であり，1 次共振モードのみを考慮しても 図 1(b) の様に振動が残る。そこで本論文では，2 慣性系の 状態オブザーバのフィードバックの構造のまま 3 慣性系の 閉ループ伝達関数の周波数特性を考慮することにより, 振動 抑制を実現することを新しく提案する。その結果，図 1(c) のように振動を完全に抑圧できる制御系を実現する。本論 文では，提案する制御系の有効性とツインドライブシステ ムの 3 慣性系モデリングの妥当性を確認する。

さらにツインドライブシステムに用いる左右の 2 つのモー 夕は摩擦状態に相違があるとき, 反力オブザーバによる力 推定に影響を与えることがある。そこで本論文では左右 2 つのモータの摩擦状態が異なる場合でも摩擦フリーシステ 


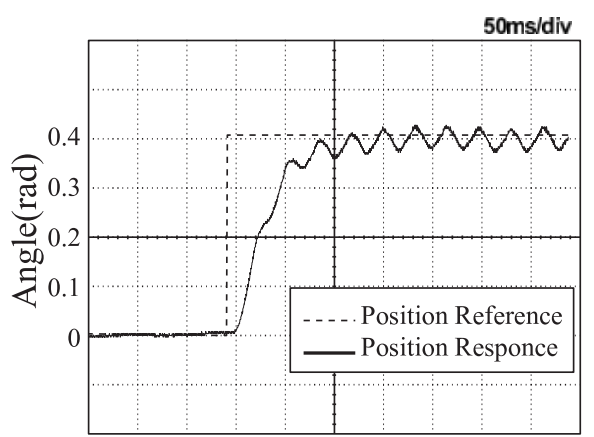

(a) The controller without vibration suppression control

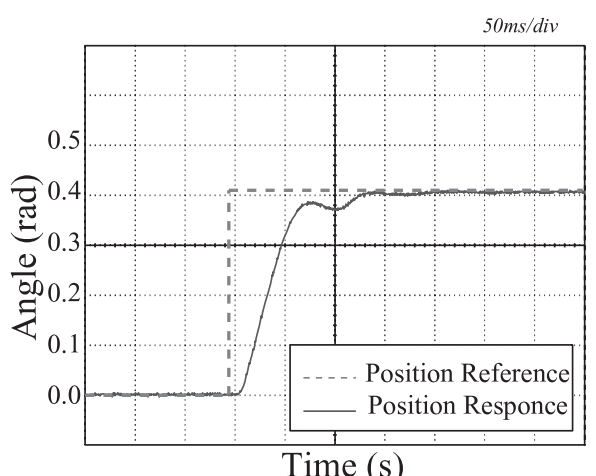

(b) Conventional controller using 2-mass parameter (Controller (1))

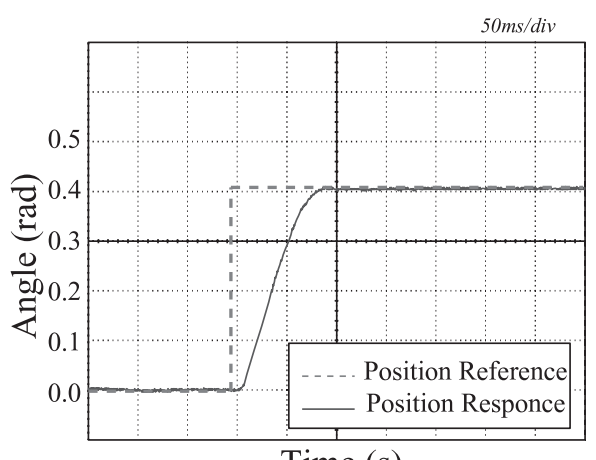

Time (s)

(c) Proposed controller using 3-mass parameter (Controller (3))

図 1 バイラテラルシステムのスレーブ制御系の 位置応答

Fig. 1. Position response of slave controller for bilateral system

ムを実現する方法も新しく提案する。

\section{2. ツインドライブシステムの 3 慣性モデル}

ツインドライブシステムは, 2 つギア付きモータを用い

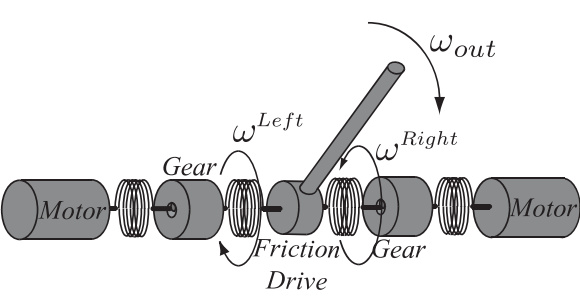

図 2 ツインドライブシステムの概念図

Fig. 2. Configuration of the twin drive system

て 1 軸のロボットアームを駆動するシステムであり，制御 対象のロボットアームの速度は (3) 式のように左右のモー 夕の速度差 $\omega_{\text {out }}$ となる。

$$
\begin{aligned}
& \omega_{\text {out }}=\omega_{-}^{\prime}=\frac{1}{2}\left(\omega^{\text {Left }}-\omega^{\text {Rihgt }}\right) . \\
& \omega_{+}^{\prime}=\frac{1}{2}\left(\omega^{\text {Left }}+\omega^{\text {Right }}\right) \cdots \cdots \cdots
\end{aligned}
$$

つまり左右のモータ自身が非線形摩擦の影響を受けていて も，その差分である出力には摩擦の影響が現れなくなる。 またその逆に両モータの和を (4) 式のように考えると, こ ちらにはクーロン摩擦の影響が現れてくる。すなわちツイ ンドライブシステムでは, 両モータの差のモードで出力の 制御を行い, 和のモードで摩擦の補償を行っていると考え ることができる。両モードを「和の座標」「差の座標」とし て新たな座標系として考え,「差の座標」で摩擦フリーシス テムを実現する ${ }^{(9)}$ 。

しかしながら，ギアを使用するシステムでは軸ねじり剛 性が低下し，共振周波数を持つことが一般的に知られてい る。そこで, ツインドライブシステムに存在する 3 つの慣 性体を分離し，その間をバネ定数 $K$ を持ったバネで結合 されている図 2 のようなモデル化を行う。このブロック図 表現が図 3 となり, 差動機構の両側を 3 慣性共振系で表現 する。

3 慣性モデルにおける差の座標系と和の座標系の出力 $\omega_{-}$, $\omega_{+}$は左右それぞれに加わる摩擦トルクを $\tau_{f}$ とすると, (1) 式と (2) 式となる。差の座標系は出力となる最終段（第 3 慣 性）に，直接取り付けられたエンコーダをフィードバック するため，(1) 式は最終段（第 3 慣性）の出力になっており, 2 つの共振周波数 $\omega_{r 1}, \omega_{r 2}$ 及びその減衰率 $\zeta_{r 1}, \zeta_{r 2}$ が存在 する。和の座標系では最終段 (第 3 慣性) の速度を直接得 ることができない。よって, モータエンコーダをフィード バックしており，(2) 式はモー夕軸（第 1 慣性）の出力であ り, 2 つの反共振周波数 $\omega_{a 1}, \omega_{a 2}$ 及びその減衰率 $\zeta_{a 1}, \zeta_{a 2}$

$$
\begin{aligned}
& \omega_{-}=\frac{1}{2(s+\alpha)} \frac{N_{0} \tau_{-}}{\left(s^{2}+2 \zeta_{r 1} \omega_{r 1} s+\omega_{r 1}^{2}\right)\left(s^{2}+2 \zeta_{r 2} \omega_{r 2} s+\omega_{r 2}^{2}\right)}=\frac{1}{2} \frac{N_{0} \tau_{-}}{s^{5}+d_{4} s^{4}+d_{3} s^{3}+d_{2} s^{2}+d_{1} s+d_{0}} \\
& \omega_{+}=\frac{N_{0}^{\prime}\left(s^{2}+2 \zeta_{a 1} \omega_{a 1}+\omega_{a 1}^{2}\right)\left(s^{2}+2 \zeta_{a 2} \omega_{a 2}+\omega_{a 2}^{2}\right)\left(\tau_{+}-2 \tau_{f}\right)}{2(s+\alpha)\left(s^{2}+2 \zeta_{r 1} \omega_{r 1} s+\omega_{r 1}^{2}\right)\left(s^{2}+2 \zeta_{r 2} \omega_{r 2} s+\omega_{r 2}^{2}\right)}=\frac{1}{2} \frac{N_{0}^{\prime}\left(s^{4}+n_{3} s^{3}+n_{2} s^{2}+n_{1} s+n_{0}\right)\left(\tau_{+}-2 \tau_{f}\right)}{s^{5}+d_{4} s^{4}+d_{3} s^{3}+d_{2} s^{2}+d_{1} s+d_{0}} . \\
& \tau_{-}=K_{t} I^{\text {Left }}-K_{t} I^{\text {Right }}, \quad \tau_{+}=K_{t} I^{\text {Left }}+K_{t} I^{\text {Right }}, \quad N_{0}=\frac{K_{2} K_{1} K_{t}}{R_{2} R_{1} J_{3} J_{2} J_{1}}, \quad N_{0}^{\prime}=\frac{1}{J_{3}}
\end{aligned}
$$


と 2 つの共振周波数が存在する。

図 3 のモデルの妥当性を確認するために, ツインドライ ブシステムの差の座標系のトルク入力 $\tau_{-}$から, リンク出 力 $\left(\omega_{-}\right)$までの周波数特性を計測した。その開ループ周波 数特性を図 4 に示す。周波数応答には, $50[\mathrm{~Hz}]$ と $80[\mathrm{~Hz}]$ の 2 点に共振周波数が現れており，3慣性系であることが 確認できる。

$$
\begin{aligned}
& \omega_{r 1}=\frac{\sqrt{2}}{2} \sqrt{\Omega_{r}-\sqrt{\Omega_{r}^{2}-4 X_{r}}} \ldots \ldots \ldots . \\
& \omega_{r 2}=\frac{\sqrt{2}}{2} \sqrt{\Omega_{r}+\sqrt{\Omega_{r}^{2}-4 X_{r}}} \ldots \ldots \ldots \ldots \\
& \omega_{a 1}=\frac{\sqrt{2}}{2} \sqrt{\Omega_{a}-\sqrt{\Omega_{a}^{2}-4 X_{a}}} \ldots \ldots \ldots . \\
& \omega_{a 2}=\frac{\sqrt{2}}{2} \sqrt{\Omega_{a}+\sqrt{\Omega_{a}^{2}-4 X_{a}}} \ldots \ldots \ldots \ldots \\
& \tau_{-}=\tau_{m}^{\text {Left }}-\tau_{m}^{\text {Right }}, \quad \tau_{+}=\tau_{m}^{\text {Left }}+\tau_{m}^{\text {Right }}
\end{aligned}
$$

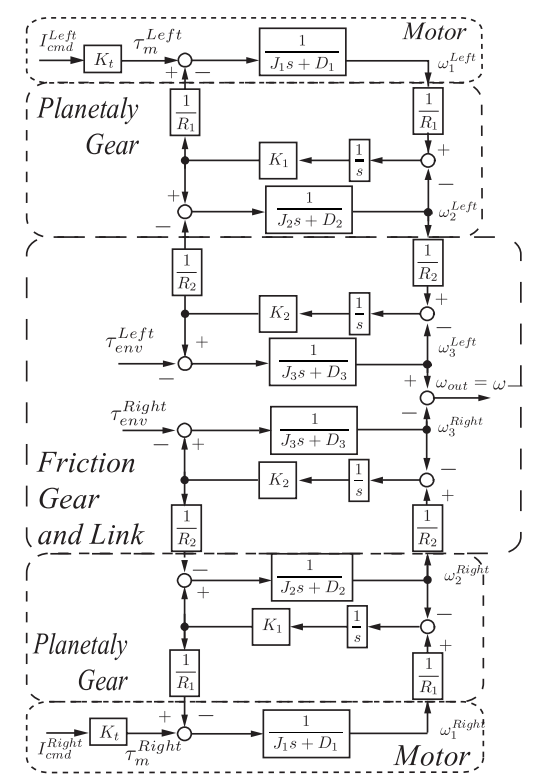

図３３慣性系で表現したツインドライブシステム Fig. 3. Block diagram of twin drive system expressed by 3 mass system

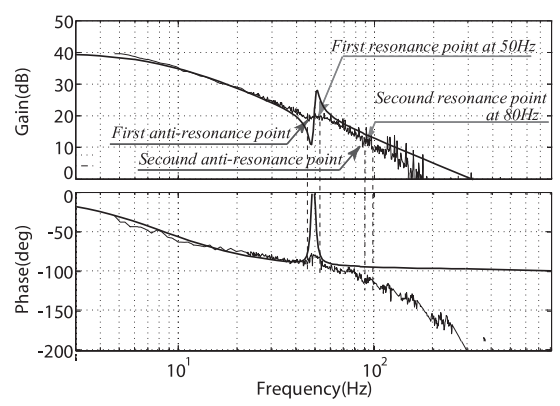

図 4 ツインドライブシステムの開ループ周波数特性

Fig. 4. Frequency characteristic of twin drive system by open-loop system

$$
\begin{aligned}
& \Omega_{r}=\frac{K_{1}}{J_{1} R_{1}^{2}}+\frac{K_{1}}{J_{2}}+\frac{K_{2}}{J_{2} R_{2}^{2}}+\frac{K_{2}}{J_{3}}, \\
& X_{r}=\frac{K_{1} K_{2}}{J_{1} J_{3} R_{1}^{2}}+\frac{K_{1} K_{2}}{J_{2} J_{3}}+\frac{K_{1} K_{2}}{J_{1} J_{2} R_{1}^{2} R_{2}^{2}} \\
& \Omega_{a}=\frac{K_{2}}{J_{3}}+\frac{K_{2}}{J_{2} R_{2}^{2}}+\frac{K_{1}}{J_{2}}, \quad X_{a}=\frac{K_{1} K_{2}}{J_{2} J_{3}}, \\
& N_{0}=\frac{K_{1} K_{2}}{J_{1} J_{2} J_{3} R_{1} R_{2}}
\end{aligned}
$$

\section{2 慣性状態オブザーバによる 3 慣性システムの制 振制御}

〈3・1〉 制振制御系の構成ツインドライブシステム では，和と差の仮想モー夕と呼ばれる座標変換を用いるこ とで, 出力の制御を行う差の成分と, 摩擦の補償を行う和の 成分に分けて考えることができる。摩擦の補償を行う和の 座標では, 両モータが回転し続けることで, 非線形な静止 摩擦が出力に現れないようにして, 差の座標では線形的に 扱える粘性摩擦だけになるように制御を行う。よって，制 振制御系は各仮想座標形上に速度制御系として構成する。

制振制御系は，(10) 式で示すようにPI 速度制御系と状 態フィードバック制御系を用いて, 図 5 のように実現す る $^{(10)(11)}$ 。

状態フィードバック制御系に用いるオブザーバは，1 次 共振のみを考慮する 2 慣性系のパラメータを用いて設計し, 制御系の構成を簡易化している。そのためフィードバック する状態量は, (10) 式で示すように, モー夕速度 $\omega_{m}$, 負荷 速度 $\omega_{L}$, 軸ねじり角 $\theta_{S}$ となる。

$$
\begin{gathered}
I^{c m d}=\left(\frac{K_{p} s+K_{i}}{s}\right) \omega^{e r r}-\boldsymbol{F} \boldsymbol{x} \ldots \ldots \ldots \\
\boldsymbol{F}=\left[F_{m}, F_{L}, F_{s}\right], \quad \boldsymbol{x}=\left[\omega_{m}, \omega_{L}, \theta_{s}\right]^{T}
\end{gathered}
$$

これを 3 慣性系で考えると, それぞれ第 1 慣性の速度 $\omega_{1}$, 第 3 慣性の速度 $\omega_{3}$, 第 1-2 慣性間のねじり角と第 2-3 慣性 間のねじり角の総和となる $R_{1} \theta_{12}+R_{1} R_{2} \theta_{23}$ をフィードバッ クしていることと同等になる。

そこで, オブザーバ推定值の妥当性を確認するために, シ

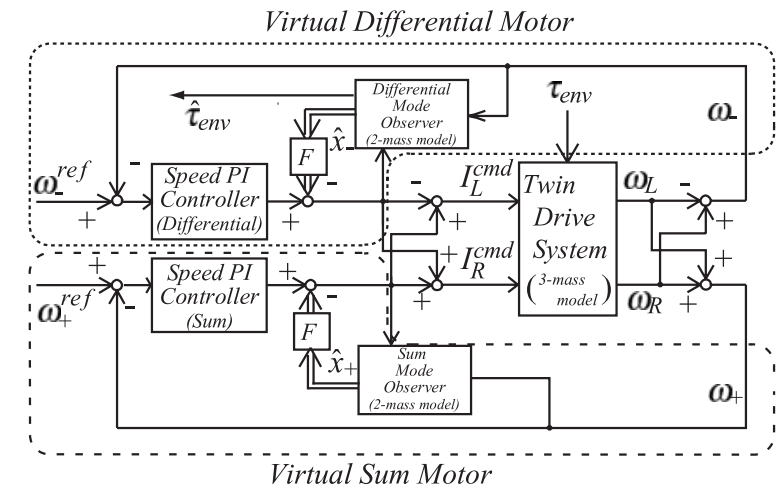

図 5 ツインドライブシステムの速度制御系の構成

Fig. 5. Speed controller for twin drive system 


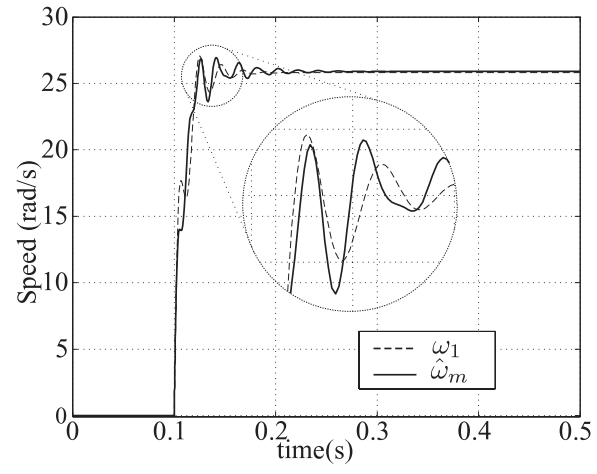

(a) motor speed

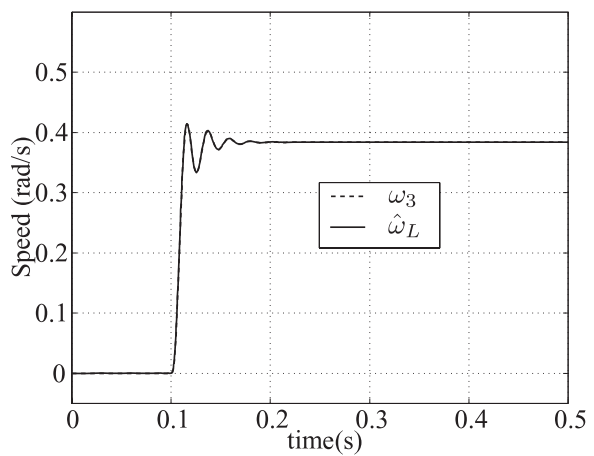

(b) load side speed

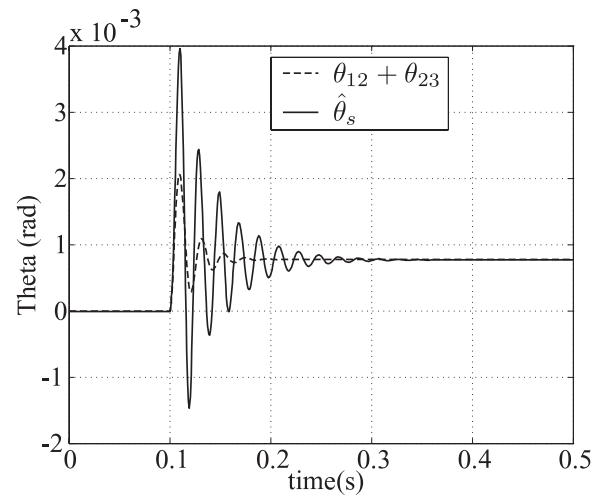

(c) total torsion angle

図 62 慣性オブザーバのシミュレーション結果

Fig. 6. Simulation results of the observer using 2-mass parameter

ミュレーションを行った。 3 慣性系のプラントの状態量を 2 慣性系で設計を行ったオブザーバにて推定した状態量を 図 6 に示す。定常值においていずれも実状態量と推定值が 一致しているのが確認できる。特に負荷側の速度は過渡応 答においても完全に一致している。

(10) 式をフィードバックすることで, 制御系全体の伝達 関数は (11) 式となる。

$$
\begin{aligned}
& G=\frac{b_{1} s+b_{0}}{s^{6}+a_{5} s^{5}+a_{4} s^{4}+a_{3} s^{3}+a_{2} s^{2}+a_{1} s+a_{0}} \cdots \cdots(11) \\
& b_{1}=K_{p} n_{a 0}, \quad b_{0}=K_{I} n_{a 0}, \quad a_{5}=-n_{g 3} F_{m}+c_{4} \\
& a_{4}=-n_{g 2} F_{m}-\frac{n_{g 3}}{R_{1}} F_{s}+c_{3}, \quad a_{3}=-n_{g 1} F_{m}-\frac{n_{g 2}}{R_{1}} F_{s}+c_{2} \\
& a_{2}=-n_{g 0} F_{m}-\frac{n_{g 1}}{R_{1}} F_{s}+c_{1} \quad a_{0}=n_{a 0} K_{I}
\end{aligned}
$$

$$
\begin{aligned}
a_{1}= & -n_{a 0} R_{2} R_{1} F_{m}-\frac{n_{g 0}}{R_{1}} F_{s}-n_{a 0} F_{L}+n_{a 0} K_{p}+c_{0} \\
c_{4}= & \frac{D_{1}}{J_{1}}+\frac{D_{2}}{J_{2}}+\frac{D_{3}}{J_{3}}, \\
c_{3}= & \frac{D_{1} D_{2}}{J_{1} J_{2}}+\frac{D_{2} D_{3}}{J_{2} J_{3}}+\frac{D_{1} D_{3}}{J_{1} J_{3}}+\frac{K_{1}}{J_{1} R_{1}^{2}}+\frac{K_{1}}{J_{2}}+\frac{K_{2}}{J_{2} R_{2}^{2}}+\frac{K_{2}}{J_{3}} \\
c_{2}= & \frac{K_{1} D_{1}}{J_{2} J_{1}}+\frac{K_{2} D_{2}}{J_{3} J_{2}}+\frac{K_{2} D_{3}}{J_{3} J_{2} R_{2}^{2}}+\frac{K_{2} D_{1}}{J_{2} J_{1} R_{2}^{2}}+\frac{K_{2} D_{1}}{J_{3} J_{1}} \\
& +\frac{K_{1} D_{2}}{J_{2} J_{1} R_{1}^{2}}+\frac{D_{3} D_{2} D_{1}}{J_{3} J_{2} J_{1}}+\frac{K_{1} D_{3}}{J_{3} J_{2}}+\frac{K_{1} D_{3}}{J_{3} J_{1} R_{1}^{2}} \\
c_{1}= & \frac{K_{2} K_{1}}{J_{2} J_{1} R_{2}^{2} R_{1}^{2}}+\frac{K_{2} K_{1}}{J_{3} J_{2}}+\frac{K_{2} K_{1}}{J_{3} J_{1} R_{1}^{2}}+\frac{K_{1} D_{3} D_{2}}{J_{3} J_{2} J_{1} R_{1}^{2}} \\
& +\frac{K_{1} D_{3} D_{1}}{J_{3} J_{2} J_{1}}+\frac{K_{2} D_{2} D_{1}}{J_{3} J_{2} J_{1}}+\frac{K_{2} D_{3} D_{1}}{J_{2} J_{2} J_{1} R_{2}^{2}} \\
c_{0}= & \frac{K_{2} K_{1} D_{1}}{J_{3} J_{2} J_{1}}+\frac{K_{2} K_{1} D_{2}}{J_{3} J_{2} J_{1} R_{1}^{2}}+\frac{K_{2} K_{1} D_{3}}{J_{3} J_{2} J_{1} R_{2}^{2} R_{1}^{2}} \\
n_{g 3}= & \frac{K_{t}}{J_{1}}, \quad n_{g 2}=\frac{D_{2} K_{t}}{J_{2} J_{1}}+\frac{D_{3} K_{t}}{J_{3} J_{1}} \\
n_{g 1}= & \frac{K_{1} K_{t}}{J_{2} J_{1}}+\frac{D_{3} D_{2} K_{t}}{J_{3} J_{2} J_{1}}+\frac{K_{2} K_{t}}{J_{2} J_{1} R_{2}^{2}}+\frac{K_{2} K_{t}}{J_{3} J_{1}} \\
n_{g 0}= & \frac{D_{3} K_{1} K_{t}}{J_{3} J_{2} J_{1}}+\frac{D_{3} K_{2} K_{t}}{J_{3} J_{2} J_{1} R_{2}^{2}}+\frac{D_{2} K_{2} K_{t}}{J_{3} J_{2} J_{1}}, \\
n_{a 0}= & \frac{K_{2} K_{1} K_{t}}{R_{2} R_{1} J_{3} J_{2} J_{1}}
\end{aligned}
$$

なお，差の座標系のオブザーバでは一つの状態変数として 反力を推定し, バイラテラル制御の際に使用する。状態才 ブザーバは $-600[\mathrm{rad} / \mathrm{s}]$ の重根として設計を行った。

制御系のフィードバック定数の設計には，係数図法 ${ }^{(12)(13)}$ を用いた。提案する手法は 3 慣性パラメー夕を用いて, 特 性が良好となるように (12) 式で示される安定度指標が (13) 式で示す標準系に近づくように，(11) 式の特性多項式の係 数 $a_{i}$ をチューニングしている。その際, 状態変数は直接 フィードバックできるとして仮定して設計を行っている。

$$
\begin{aligned}
& \gamma_{i}=a_{i}^{2} /\left(a_{i+1} a_{i-1}\right), \quad i=1 \sim n-1 \cdots \ldots \ldots \\
& \gamma_{i}^{\text {std }}=\left[\gamma_{n-1}, \cdots, \gamma_{2}, \gamma_{1}\right]=[2.0, \cdots, 2.0,2.5]
\end{aligned}
$$

今回は比較のため

制御器 (1) : 1 次共振モードだけを考慮した制御器 (広带域)

制御器 (2) ：1 次共振モードだけを考慮した制御器 (狭帯域)

制御器 (3) : 2 次共振モードも 1 次と同様に考慮した 制御器 (広帯域)

制御器 (4) ： 3 慣性系オブザーバによる完全状態 フィードバック制御器（広帯域）

の 4 つの制御器を構築した。

制御器（1）および（2）は制御対象を 2 慣性系へ近似し, 安定度指標が (14) 式, それぞれの時定数を $\tau=0.01$ と $\tau=0.02$ となるように設計を行った制御器である。 
表 13 慣性系の安定度指標

Table 1. Parameter of the stability indecies

\begin{tabular}{l|c|c|c|c|c|c}
\hline Design method & $\gamma_{5}$ & $\gamma_{4}$ & $\gamma_{3}$ & $\gamma_{2}$ & $\gamma_{1}$ & $\tau$ \\
\hline Controller (1) & 1.60 & 1.43 & 1.63 & 1.43 & 4.17 & 0.02 \\
\hline Controller (2) & 1.65 & 1.41 & 1.58 & 1.38 & 4.56 & 0.04 \\
\hline Controller (3) & $\mathbf{1 . 9 0}$ & $\mathbf{1 . 0 5}$ & $\mathbf{2 . 4 7}$ & $\mathbf{1 . 8 8}$ & $\mathbf{2 . 0 5}$ & $\mathbf{0 . 0 2}$ \\
\hline Controller (4) & 2.0 & 2.0 & 2.0 & 2.0 & 2.5 & 0.02 \\
\hline Controller (5) & 2.0 & 2.0 & 2.0 & 1.0 & 2.5 & 0.02 \\
\hline Controller (6) & 2.0 & 1.0 & 2.0 & 2.0 & 2.5 & 0.02 \\
\hline
\end{tabular}

$$
\gamma_{i}=[2.0,2.0,2.5]
$$

しかしながら実際の制御対象は 2 慣性系ではなく 3 慣性 系であるため，実現された制御系の安定度指標は表 1 に示 す值となる。そのため 3 慣性系の伝達関数では安定度指標 標準系より值が大きく離れる。これにより所望の応答を得 られなくる。

制御器（3）が提案手法であり，2 慣性系の状態オブザー バを用いたまま安定度指標が真鍋多項式の標準系に近づく ようにゲインをチューニングしている。制御器 (4) は 3 慣 性系のオブザーバを構成し, 完全状態フィードバックを行 うことで安定度指標をすべて (13) 式で示す標準系にした制 御器である。

なお, 提案法である制御器（3）の設計の際には, 安定度 指標の低次の項に重みを置いて設計を行っている。これは 安定度指標の低次の項の方が制御器の応答に影響を与える ためである。

それを示すために $\gamma_{2}$ を標準系より半分にした制御器 (5) と $\gamma_{4}$ を標準系より半分にした制御器（6）のボード線図と シミュレーション結果を図 7 に示す。 $\gamma_{2}$ を半分にした制御 器（5）はボード線図の低周波域でゲイン特性が 1 を超え ており，その影響により図 7(b) のように振動が残る結果に なっている。それに対し制御器（6）では，速度ステップ応 答には振動がほとんどなく, 安定度指標の低次の項が応答 に影響を与えていることが確認できる。

今回設計した制御器の閉ループ周波数特性を図 8(a) に示 す。また図 8(b) には, 設計した制御器の速度ステップシ ミュレーション結果を示す。2 慣性設計を行った制御器 (1) は共振の影響を完全に取り切れておらず，ゲイン特性が 1 を超えているところが見られるため，ステップ応答も振動 が残っている。提案する制御器 (3) はゲイン特性もなだら かであり，シミュレーション結果にも振動は見られない。

$\langle\mathbf{3} \cdot \mathbf{2}\rangle$ 実験結果 図 9 に設計した制御器の実機実験 の結果を示す。以前の構造の設計法による制御器 (1) の応 答は，1 次共振モードだけを考慮して設計しているので 3 慣性系で考えると, 安定度指標は表 1 に示すように標準系 から離れ, 図 9(a)に示す応答も振動が残る。そのため制御 器（2）のように帯域を狭くする必要がでる。

そこで，本論文では状態フィードバックと状態オブザー バは 2 慣性系の時と同じとし，フィードバック定数を 3 慣 性系の安定度指標を見ながら決める。制御器（3）では，(1)
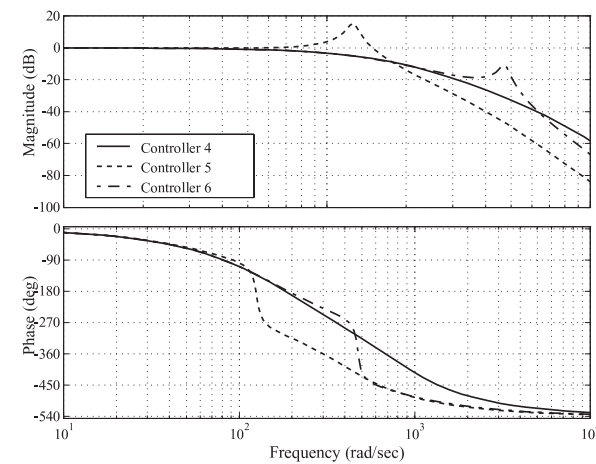

(a) Bode diagram

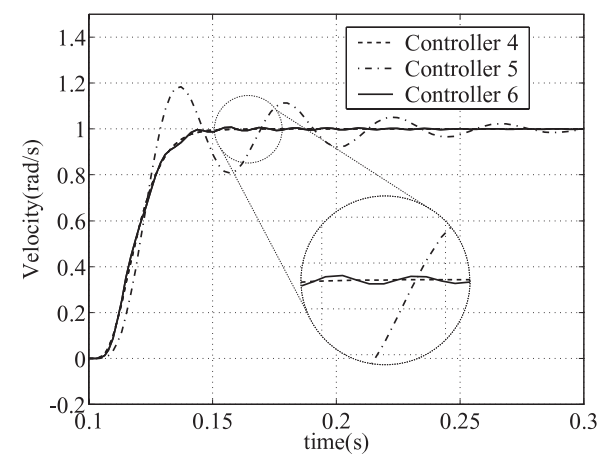

(b) Speed step response

図 7 安定度指標標準系からはなれた際のボード 線図及びシミュレーション結果

Fig. 7. Simulation results and bode diagram of speed control system using miss match stability indecies

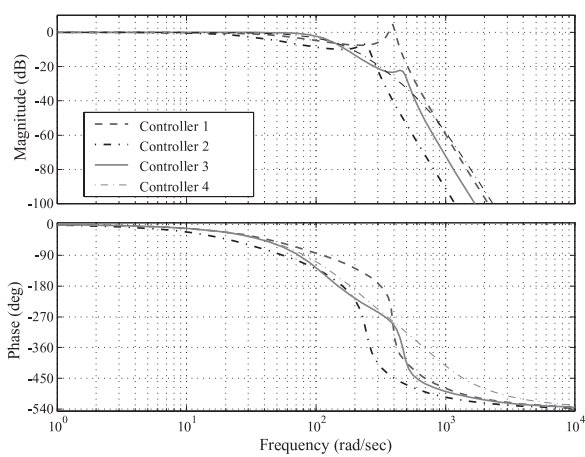

(a) Bode diagram

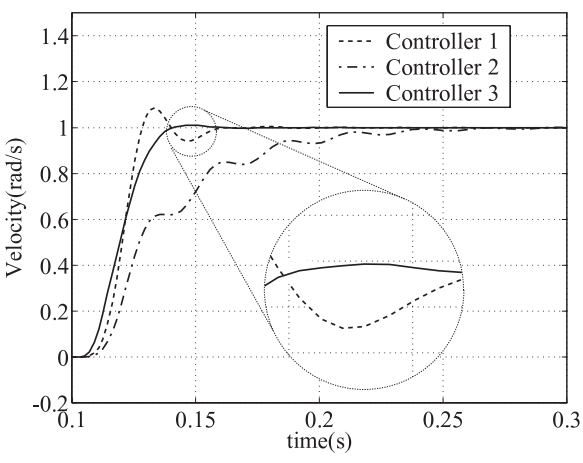

(b) Speed step response

図 8 速度制御系のシミュレーション結果

Fig. 8. Simulation results of speed control system 


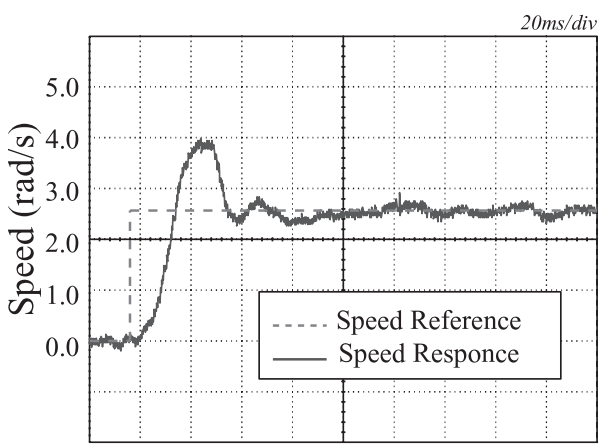

Time (s)

(a) Controller (1)

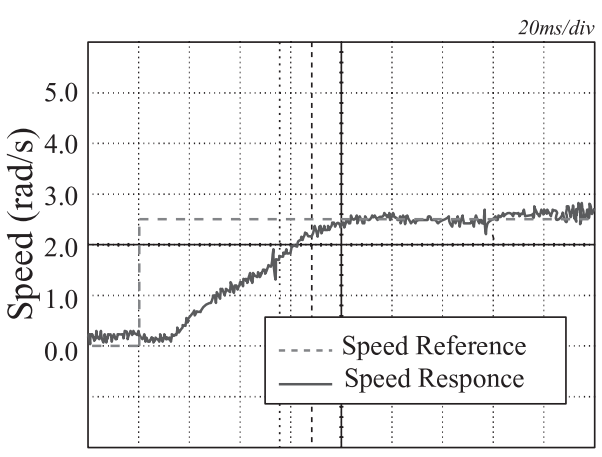

Time (s)

(b) Controller (2)

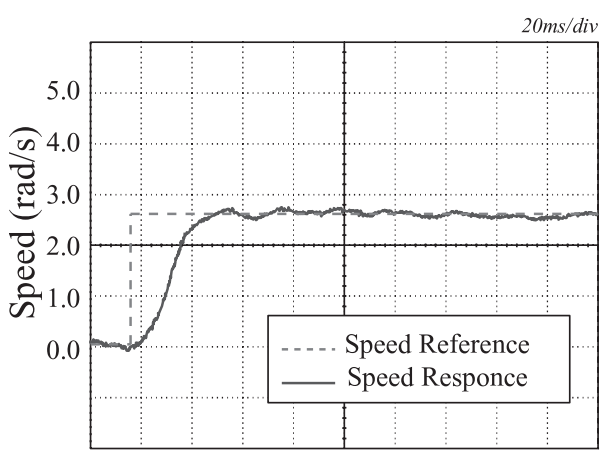

Time (s)

(c) Controller (3)

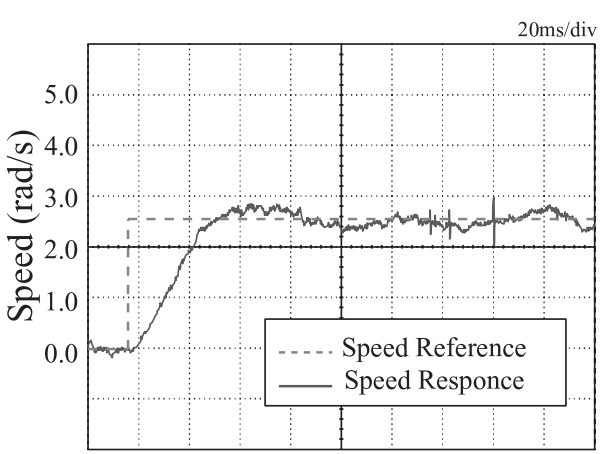

Time (s)

(d) Controller (4)

図 9 速度ステップ応答

Fig. 9. Experimental results of the speed response using twin drive system
に比べて安定度指標をより標準系に近づけてあり，図 9(c) に示す応答も振動が抑圧できている。また提案法の応答は, 3 慣性系オブザーバを用いた全状態フィードバックの制御 器 (4) の図 9(d) と比較しても遜色がない。なお，図 8(b) の シミュレーション結果と図 9 の実験結果とで応答に微妙な 差異が生じているのは, 実プラントモデルと状態オブザー バのモデルのパラメータを，完全一致させることができな かったためによるものと思われる。

\section{4. ツインドライブシステムの不平衡摩擦補償}

図 10 は, ツインドライブシステムの出力である差の座 標軸の速度出力 $\omega_{-}$を横軸にとり，縦軸にそのときの駆動 トルク $\tau_{-}$をプロットしたグラフである。図において，和の 座標軸の速度 $\omega_{+}$を $200[\mathrm{rad} / s]$ にすると, 差動軸の出力速 度 $\omega_{-}=0[\mathrm{rad} / s]$ 付近で非線形摩擦の影響が現れないこと が確認できる。

しかしながら $\omega_{+}=-200[\mathrm{rad} / s]$ の場合に, 和の座標軸の 速度指令值によってオフセットが存在することがある。こ れは実際の左右のモータのクーロン摩擦の大きさが異なり, その大きさは回転方向によって大きさが異なるため，(15) 式に示すように摩擦差がオフセットとして現れてくると考

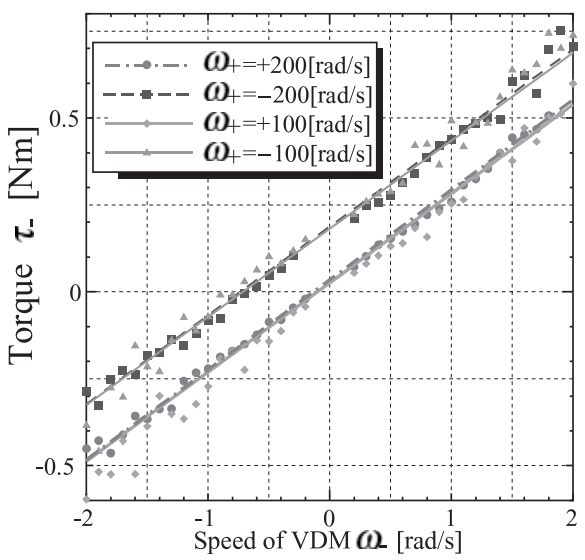

図 10 定速度試験結果

Fig. 10. Constant speed test result

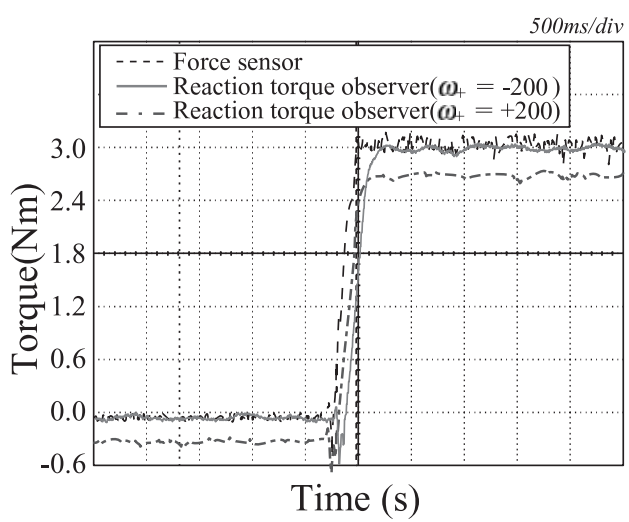

図 11 反力推定結果

Fig. 11. Experimental results of the reaction torque estimation 
えられる。

$$
\begin{aligned}
& \tau^{\text {Left }}-\tau^{\text {Right }}=D \omega^{\text {Left }}-D \omega^{\text {Right }}-\left(\tau_{f}^{\text {Left }}-\tau_{f}^{\text {Right }}\right) \\
& \tau_{-}=D \omega_{-}\left(\tau_{f}^{\text {Left }}-\tau_{f}^{\text {Right }}\right) \cdots \cdots \cdots \cdots \cdots \cdots \cdots \cdots
\end{aligned}
$$

図 11 はツインドライブシステムに外よりステップ上の 反力を入力した際の反力推定結果を和の仮想モータの速度 指令值を変化させて取得したものである。 $\omega_{+}=200[\mathrm{rad} / \mathrm{s}]$ の時は差の座標軸上のクーロン摩擦，すなわち摩擦差の オフセットが少ないので良好な力制御が行える。それに対 し, $\omega_{+}=-200[\mathrm{rad} / \mathrm{s}]$ の時は推定誤差が生じている。摩 擦差のオフセットより和の座標の速度指令值を本論文では $\omega_{+}=200[\mathrm{rad} / \mathrm{s}]$ に設定している。

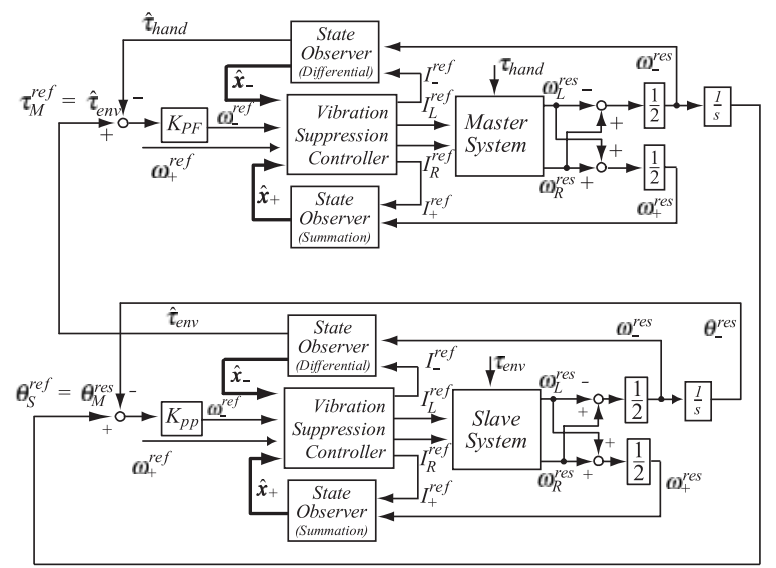

図 12 力帰還型バイラテラル制御系

Fig. 12. Bilateral control system

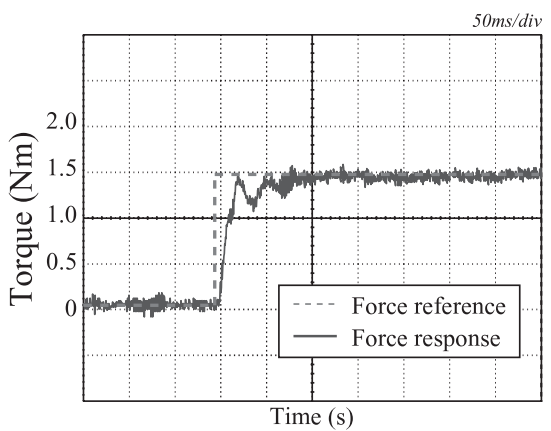

(a) Controller (1)

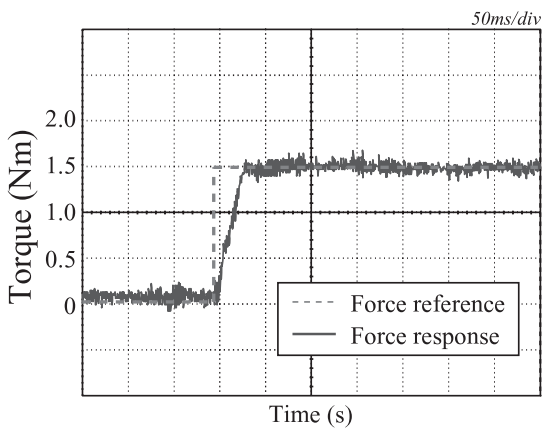

(b) Controller (3)

図 13 マス夕制御系の力応答

Fig. 13. Force response of master controller

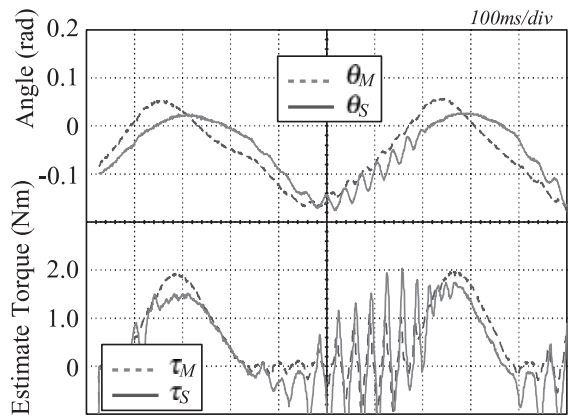

(a) Without vibration suppression controller

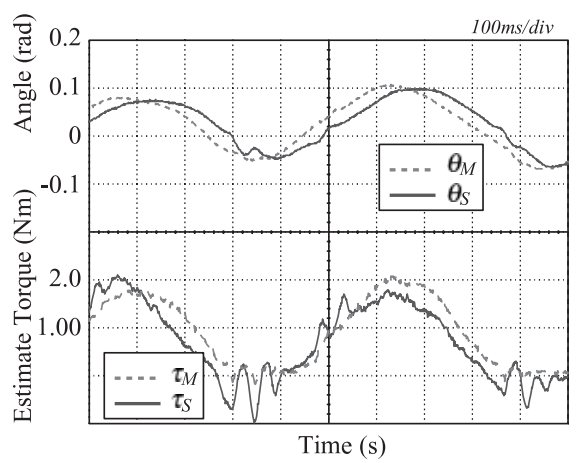

(b) Controller (1)

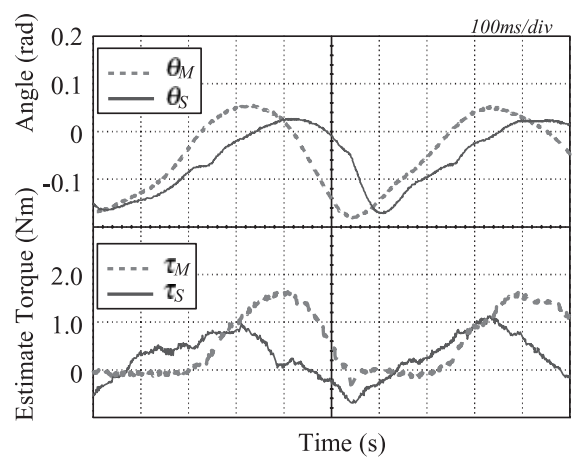

(c) Controller (2)

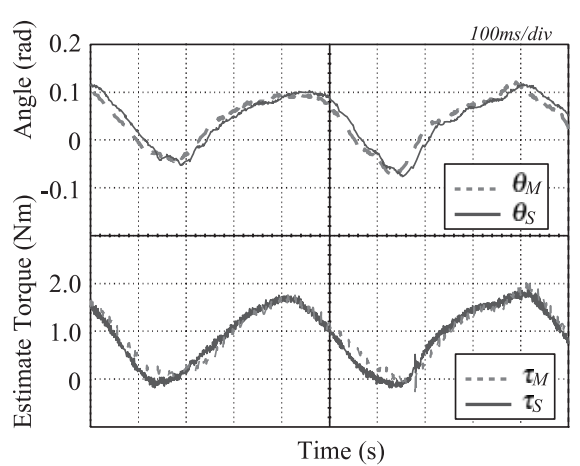

(d) Controller (3)

図 14 ツインドライブシステムを用いた バイラテラル応答結果

Fig. 14. Experimental results of the bilateral response using twin drive system 


\section{5. バイラテラルシステム}

〈5・1〉 力帰還型バイラテラルシステム＼cjkstart本論文では提 案する制振制御系をバイラテラルシステムへ適用する。提 案法の有効性を確認するために, 力帰還型バイラテラルシ ステムを構築する ${ }^{(14)}$ 。力㷌還型バイラテラルシステムは, マスタを力制御としてスレーブの作業反力を操作者へ伝え, スレーブの位置制御系で操作者の望む動作を実現する方式 である。

マスタ・スレーブ制御系は図 12 として，それぞれ提案す る制振制御系をマイナーループとする制御系として構築し た ${ }^{(15)}$ 。軸ねじり振動を抑圧することで帯域の向上が望め, さらに反力オブザーバの推定值も軸ねじりトルクの影響を 受けないため, 良好な力情報が得られる。これは, 反力オ ブザーバの極を $-600[\mathrm{rad} / \mathrm{s}]$ という比較的広帯域に実現で きたことによるものである。そのためよりよい操作感が得 られると考えられる。

〈5・2〉 実験結果＼cjkstart提案するバイラテラル制御系を構 築して，提案法の有効性を確認する実機実験を行った。

最初にマス夕側に用いられる力制御系の応答を確認する。 2 慣性系パラメータで設計を行う制御器（1）と，3 慣性系 パラメー夕を考慮する制御器（3）のそれぞれを用いて，口 ボットアームにて一定力でスチール缶を押しつける指令を 与えた。その結果を図 13 に示す。従来法では振動が残り あまり良くない過渡特性であるが，提案法では改善されて いる。

次にスレーブ制御系においても，先に示した図 1 のよう に良好な制御が行えている。

最後に，マスタ・スレーブ型バイラテラルロボットを用 いて，実際に人間がマスタロボットを操作し，スレーブロ ボットでプラスチック片に複数回接触する試験を行った。 図 14(a)に制振制御を行わないPI 制御系の結果，図 14(b) に2 慣性系設計の結果, 困 14(d) に3 慣性系設計の結果を 示す。PI 制御系の結果では, 非常に大きな振動が残ってし まっているのが確認できる。それに対して 2 慣性系設計で は，多少改善ができているが，位置，力共に振動が見られ るため，図 14(c) のように帯域を下げる必要がある。その ため，応答が鈍くなってしまっている。ところが，3慣性 系設計を行うことでその振動を抑圧できている。また，実 際の操作感も振動のない提案法の方が良くなっている。

\section{6. 結 論}

本論文では，ツインドライブシステムを 3 慣性モデルで モデリングし，その妥当性を検証した。また，モー夕の個 体差によるクーロン摩擦の特性差も考慮することにより, よりシステムに摩擦の影響を受けにくい指令值について検 討した。ツインドライブシステムの詳細モデルに対して， 従来用いてきた 2 慣性系で設計を行ったオブザーバを用い て，制御系を複雑にすることなく制振特性を向上できるこ とを示した。最後に提案する制御系をバイラテラル制御系
へ応用することで，従来以上に制御帯域が向上し，マスタ. スレーブ間でより良好な触覚を伝達できることを確認した。 本手法を応用することで，ギアを使用したバイラテラル制 御系の性能を改善できると考えられる。

(平成 17 年 7 月 4 日受付，平成 18 年 5 月 15 日再受付)

\section{文献}

(1) K. Ohishi, M. Miyazaki, and M. Fujita: "Hybrid Position and Force Control without Force Sensor", Journal of RSJ, Vol.11, No.3, pp.468-476 (1993-3) (in Japanease)

大石 潔·宮崎 勝 ·藤田昌弘：「力センサを用いない位置と力の ハイブリッド制御」, 日本ロボット学誌, 11, 3, pp.468-476 (1993-3)

(2) K. Ohishi, M. Miyazaki, and M. Fujita: "Sensorless Force Control Based on $H^{\infty}$ Control Theory", T. IEE Japan IA, Vol.112-D, No.9, pp.852-861 (1992-9) (in Japanease)

大石 潔・宮崎 勝・藤田昌弘：「H皮制に基づくセンサレス力制 御」, 電学論 D, 112, 9, pp.852-861 (1992-9)

(3) T. Murakami, R. Nakamura, F. Yu, and K. Ohnishi: "Force Sensorless Compliant Control Based on Reaction Force Estimation Observer in Multi-Degree-ofFreedom Robot", Journal of RSJ, Vol.11, No.5, pp.765-768 (1993-5) (in Japanease)

村上俊之 ·中村 亮・郁 方銘・大西公平：「反作用力推定オブザー バに基づいた多自由度ロボットのカセンサレスコンプライアンス制 御」, 日本ロボット学誌, 11, 5, pp.765-768 (1993-5)

(4) N. Hayashida, T. Yakoh, T. Murakami, and K. Ohnishi: "A Sensorless Force Control in Twin Drive System”, Proc. of IEEE. IES. IECON'2000, pp.2231$2236(2000)$

(5) K. Shibata, T. Murakami, and K. Ohnishi: "Torque Sensorless Control of Twin Drive System by Virtual Motor Model”, Proc. of JSME. International Conference on Motion and Vibration Control (MOVIC), Vol.2, pp.669-674 (1994)

(6) N. Hayashida, T. Yakoh, T. Murakami, and K. Ohnishi: "A Friction Compensation in Twin Drive System", 6th International Workshop on Advanced Motion Control (AMC), pp.187-192 (2000)

(7) T. Miyazaki, K. Ohishi, A. Hashimoto, and T. Nakatsuka: "Robust Speed Control for Robot Arm Considering Angular Transmission Error of Gear", T. IEE Japan IA, Vol.118-D, No.12, pp.1427-1434 (1998-12) (in Japanese) 宮崎敏昌・大石 潔・橋本敦実・中塚 隆:「ギアの角度伝達誤差を 考慮したロボットアームのロバスト速度制御系の一構成法」, 電学論 D, 118, 12, pp.1427-1434 (1998-12)

(8) Y. Ohba and K. Ohishi: "Force-Reflecting Type Friction Free Bilateral System Based on Twin Drive Control System with Torsional Vibration Suppression”, IEEJ Trans. IA, Vol.125, No.6, pp.575-581 (2005-6) (in Japanese) 大場 譲・大石 潔：「軸ねじり振動を抑制したツインドライブシ ステムによる力帰還型摩擦フリーバイラテラルシステム」, 電学論 D, 125, 6, pp.575-581 (2005-6)

(9) S. Katsura and K. Ohnishi: "Transmission and Reproduction of Force Sensation by Bilateral Contrl", IEEJ Trans. IA, Vol.123, No.11, pp.1371-1376 (2003-11) (in Japanease)

桂誠一郎・大西公平：「バイラテラル制御による力覚の伝達と再現」, 電学論 D, 123, 11, pp.1371-1376 (2003-11)

(10) Y. Hori, H. Iseki, and K. Sugiura: "Basic Consideration of Vibration Suppression and Disturbance Rejection Control of Multi-inertia System using SFLAC (State Feedback and Load Acceleration Control)", IEEE Trans. Industry Appl., Vol.30, No.4, pp.889-896 (1994-4)

(11) T. Miyazaki, S. Otaki, S. Tungpataratanawon, and K. Ohishi: "High Speed Motion Control Method of Industrial Robot Based on Dynamic Torque Compensation and Two-Degree-of-Freedom Control System", IEEJ Trans. IA, Vol.123, No.5, pp.525-532 (2003-5) (in Japanease)

宮崎敏昌・大瀧 栄・ソムサワッス・タンパタラタナウォン・大石 潔: 「動力学トルク補償と 2 自由度制御系に基づく産業用ロボット の高速モーション制御法」, 電学論 D, 123, 5, pp.525-532 (2003-5)

(12) S. Manabe: "The Application of Coefficient Diagram Method to ACC Benchmark Problem", Proc. of 2nd Asian Control Conference, II-135-138 (1997)

(13) S. Manabe: "Controller Design of Two-Mass Resonant System by Coefficient Diagram Method", T. IEE Japan, Vol.118-D, No.1, pp.58-66 (1998-1) (in Japanease)

真鍋舜治：「係数図法による 2 慣性共振系制御器の設計」, 電学論 D, 118, 1, pp.58-66 (1998-1)

(14) D. Kwon, K. Woo, and H. Cho, "Haptic Control of the Master Hand Con- 
troller for a Microsurgical Telerobot System", Proc. of IEEE. International Conference on Robotics \& Automation (ICRA'1999), pp.1722-1727 (1999)

（15）大石 潔：「1 自由度系のモーションコントロール（メカ，アクチュ エータ, 電力変換器, マイナーループ, メインループ)」, 計測と制 御, Vol.39, No.10, pp.608-614 (2000-10)

大 場 譲 (学生員) 1980 年 1 月 11 日生。 2002 年 3 月長 岡技術科学大学電子機器工学課程卒業。2004 年 3 月同大学電気・電子システム工学専攻修了。同年 4 月同大学院エネルギー・環境工学専攻博士課程 入学。現在主として, モーションコントロールと ロボティクスに関する研究に従事。

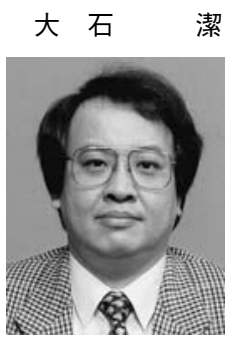

（上級会員） 1957 年 10 月 14 日生。1986 年 3 月， 慶應義塾大学大学院工学研究科博士課程修了。大 阪工業大学講師, 助教授を経て, 1993 年 4 月長 岡技術科学大学電気系助教授, 2003 年より長岡技 術科学大学大学電気系教授, 現在に至る。工学博 士。主として制御工学, パワーエレクトロニクス, ロボティクスに関する研究に従事。IEEE Member など。

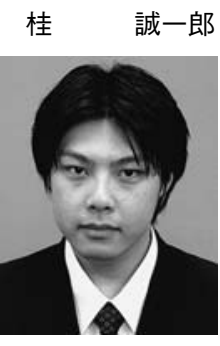

（正員） 1978 年 9 月 23 日生。 2001 年 3 月慶應 義塾大学理工学部システムデザイン工学科卒業。 2004 年 9 月同大学大学院理工学研究科総合デザ イン工学専攻後期博士課程修了。2003 年 4 月か ら 2005 年 3 月まで日本学術振興会特別研究員。 2005 年 4 月より長岡技術科学大学電気系助手, 現在に至る。主としてモーションコントロール， ハプティクス，ロボティクスの研究に従事。博士 (工学)。 